\title{
Group Investigation Model in Environmental Learning: An Effect for Students' Higher Order Thinking Skills
}

\author{
Ratna Komala*, Dzikrina Puji Lestari, Ilmi Zajuli Ichsan \\ Department of Biology Education, Faculty of Mathematics and Natural Science, Universitas Negeri Jakarta, Indonesia
}

Received September 15, 2019; Revised January 27, 2020; Accepted March 24, 2020

Copyright $\odot 2020$ by authors, all rights reserved. Authors agree that this article remains permanently open access under the terms of the Creative Commons Attribution License 4.0 International License.

\begin{abstract}
Group investigation is a learning model that emphasizes the ability to think of students through group activities to investigate specific problems or topics. Solving problem needs an Higher Order Thinking Skills (HOTS). This is because the problem needs to be solvedwith problem analysis and evaluation, based on the competency of the students. Through this model, students can be directly involved in solving the problems encountered. This study aimed to determine the effect of the group investigation learning model on students' HOTS in environmental learning for the topic of environmental pollution. The method used in this research was an experiment with a post-test only control group design. The sample of the research was $10^{\text {th }}$ grade students selected by simple random sampling. The results of the study showed that $\mathrm{t}$-count $>\mathrm{t}$-table, which could be interpreted as an effect of the group investigation learning model on students' HOTS. The group investigation learning model made students more active and exercised their ability to analyze students. The conclusion of this study was that there was an influence in students' HOTS on the use of the group investigation model.
\end{abstract}

Keywords Environmental learning, Group investigation, HOTS

\section{Introduction}

Environmental learning in the 21 st century requires students to develop their thinking abilities. That ability needs to be trained early on, one of them being in middle school in order to be able to anticipate changes in the environment of today's changing world. Efforts can be made by the school that should teach by using a model that can improve students' thinking abilities $[1,2]$. The ability to think of students is divided into two, namely Lower Order Thinking Skills (LOTS) and Higher Order Thinking Skills
(HOTS). LOTS includes several aspects, namely remembering, understanding, and applying. Meanwhile, HOTS consists of several aspects, namely analyzing, evaluating, and creating $[3,4]$.

One model that emphasizes critical thinking is the group investigation learning model, which is a learning model that can improve students' thinking abilities $[5,6]$. HOTS includes critical thinking and creative thinking, where these two categories are not separate categories but are often found working together in the same activities [7,8]. The group investigation model can develop emotional abilities in responding to rational matters and increase success in problem-solving.

For students in applying the learning model, it is necessary to consider the characteristics of the topic to be conveyed to students. Environmental learning is a meaningful learning of science and needs problem-solving skills $[9,10]$. Environmental learning emphasizes the students' thinking process which can be done through one of them with a group investigation model. Environmental pollution was a topic with several global problems faced by humans on earth today, so that coping effort is needed through critical thinking in dealing with it. HOTS can be applied through scientific methods, then followed by class discussions on science learning that can help direct HOTS to students $[11,12]$.

Research that has been done regarding HOTS was that many students still have low scores on HOTS [2,13]. In addition, other research are related to the use of various models and strategies to improve students HOTS $[14,15]$. In this study, the focus to be solved is related to the use of the group investigation learning model. This makes this research something new because it measures HOTS indicators that focus on the use of the group investigation model. Therefore, it is necessary to conduct research to determine the effect of the group investigation learning model on students' HOTS ability on the environmental pollution topic. 


\section{Methods}

The study was conducted at the High School of Labschool Rawamangun Jakarta, in May 2015. The method used was an experiment with a group investigation learning model (X) and HOTS (Y). The study design was a post-test only control group design. Student samples were taken as many as 43 students were selected by simple random sampling. Data collection techniques were carried out through (1) HOTS test (2) students HOTS questionnaire as supporting data and through observations of learning accomplishments.

The first instrument used was the HOTS test item, which was used during the post-test after the learning activity of environmental pollution. There were 22 items with the highest score being 4 points, then 9 indicators namely: observing, generating ideas, asking questions, connecting concept, making analogies, recognizing patterns, solving problems, transforming knowledge and making synthesis $[3,16]$.

The second instrument used was the students HOTS questionnaire sheet, which used a modified Likert scale. Options of answers were often, sometimes, rarely and never. The questions consist of 41 items, consisting of 9 indicators and each indicator consists of a positive item statement and a negative item statement. The instrument was first tested and then tested for validity and reliability. Research procedures include the preparation and implementation stages. The preparation phase begins by preparing a Learning Implementation Plan and research instruments in coordination with the teacher. Then carry out the testing of the instrument and HOTS test questionnaire. The implementation stage was carried out in the experimental class with the group investigation model and the control. The class was carried out with the Student Team Achievement Division (STAD) learning model as a conventional learning model.

Treatment in the experimental class, the first meeting the teacher explains the topic of environmental pollution, students then discuss in groups to carry out investigations, with student worksheets. The second meeting, the students in groups presented the results of the investigation of problems with the 2nd student worksheet. During the study, Students' HOTS was observed by observers. The end of the lesson, students fill out the HOTS questionnaire. The third meeting, students work on a post-test in the form of a HOTS test.

Condition in the control class, the first meeting begins with the teacher giving an explanation of the topic of environmental pollution, students discussing in groups to fill in the student's worksheet about environmental pollution articles. The second meeting, the students in groups presented the results of the discussion of problems with the 2nd student worksheet. During the study, students' HOTS was observed by observers. The end of the lesson, students fill out the HOTS questionnaire. The third meeting, students work on a post-test in the form of a HOTS test. Data were analyzed using statistical analysis of the t-test at $\alpha=0.05$ and previously conducted a prerequisite test that is Kolmogorov Smirnov normality test with $\alpha=0.05$, and homogeneity test using the F test with $\alpha=0.05$. The data obtained is then classified based on HOTS.

\section{Result and Discussion}

HOTS test scores of students in the experimental class obtained the highest score of 88 and the lowest of 55, while an average of 73.68 with a standard deviation of 5.9. The criteria in this study are very low, low, moderate, high, and not found very high criteria. For more details can be seen in table 1 .

Table 1. The score of HOTS test in the experimental class

\begin{tabular}{|c|c|c|}
\hline Category & Interval Score & $\begin{array}{c}\text { Frequency of } \\
\text { students }\end{array}$ \\
\hline Very High & $90-100$ & 0 \\
\hline High & $79-89$ & 3 \\
\hline Moderate & $65-78$ & 28 \\
\hline Low & $56-64$ & 2 \\
\hline Very low & $0-55$ & 1 \\
\hline
\end{tabular}

In the control class, the highest score was 80 and 51 were affected, while the average was 70.67 with a standard deviation of 6.252. Criteria are very low, low, moderate and high and not found very high criteria. For more details can be seen in table 2 .

Table 2. The score of HOTS in the control class

\begin{tabular}{|c|c|c|}
\hline Category & Interval Score & $\begin{array}{c}\text { Frequency of } \\
\text { students }\end{array}$ \\
\hline Very High & $90-100$ & 0 \\
\hline High & $79-89$ & 4 \\
\hline Moderate & $65-78$ & 28 \\
\hline Low & $56-64$ & 1 \\
\hline Very low & $0-55$ & 1 \\
\hline
\end{tabular}

The normality test results showed a-max $=0.167$, while in the a-max control class $=0.108$. D-table value $=0.23$ at $\alpha=0.05$ and $n=34$. Because a-max <D-table in the experimental class and the control class is $0.167<0.23$ and $0.108<0.23$, both classes receive Ho which means the HOTS test score data is normally distributed.

$\mathrm{F}$ test results showed F-count $=1.118$ and F-table-1.76. Because F-count < F-table, both groups come from homogeneous populations. While the results of the t-test on students' HOTS test scores obtained t-count $=2.06$ and $\mathrm{t}$-table $=1.99$ at $\alpha=0.05$. Because $\mathrm{t}$-count $>\mathrm{t}$-table, then reject $\mathrm{Ho}$, meaning that there is an influence of the group investigation learning model on Students HOTS on the 
topic of environmental pollution. Description of HOTS questionnaire test student data scores in the experimental class obtained the highest score of 79 , the lowest 55 , an average of 71.30 with a standard deviation of 6.443 . The criteria are very low, low, moderate and high and no criteria are found very high. Can be seen in table 3

Table 3. HOTS Questionnaire Scores for Students in Experimental Classes

\begin{tabular}{|c|c|c|}
\hline Category & Interval Score & Frequency of students \\
\hline Very High & $90-100$ & 0 \\
\hline High & $79-89$ & 1 \\
\hline Moderate & $65-78$ & 25 \\
\hline Low & $56-64$ & 7 \\
\hline Very low & $0-55$ & 1 \\
\hline
\end{tabular}

For the control class, the highest score was 85 and the lowest was 63 . The average was 70.91 with a standard deviation of 4.50 for HOTS score. Criteria are very low, low, medium and high and not found very low and very high criteria. For more details, please see table 4.

Table 4. Scores of the Critical Thinking Ability Questionnaire of Students in the Control Class

\begin{tabular}{|c|c|c|}
\hline Category & Interval Score & Frequency of students \\
\hline Very High & $90-100$ & 0 \\
\hline High & $79-89$ & 2 \\
\hline Moderate & $65-78$ & 31 \\
\hline Low & $56-64$ & 1 \\
\hline Very low & $0-55$ & 0 \\
\hline
\end{tabular}

When compared with the experimental class and the control class based on the average test scores and HOTS questionnaire, it appears that the experimental class using the group investigation model is higher than the control class using the STAD method. For more details can be seen in table 5.

Table 5. Comparison of the average score of the experimental and control class

\begin{tabular}{|c|c|c|}
\hline Instrument Type & Classes & Average Score \\
\hline \multirow{2}{*}{ Test } & Experiment & 73,68 \\
\cline { 2 - 3 } & Control & 70,67 \\
\hline \multirow{2}{*}{ Questionnaire } & Experiment & 71,30 \\
\cline { 2 - 3 } & Control & 70,91 \\
\hline
\end{tabular}

The observation score of students in the experimental class based on the indicator shows that the highest score is the indicator of changing/transforming with a score of 94 , while the lowest is the score of the indicator making an analogy of 61 . For the control class, the highest score on the spec asking questions is 92 , and the lowest on the score making an analogy of 56 . More details can be seen in table 6 .
Table 6. Student observation scores based on indicators of HOTS

\begin{tabular}{|c|c|c|c|}
\hline No & Indicators & Experiment & Control \\
\hline 1 & Observe & 85 & 81 \\
\hline 2 & Generating ideas & 86 & 82 \\
\hline 3 & Asking question & 86 & 92 \\
\hline 4 & Connecting concept & 81 & 69 \\
\hline 5 & Make an analogy & 61 & 56 \\
\hline 6 & Recognize patterns & 81 & 57 \\
\hline 7 & Solve the problem & 75 & 83 \\
\hline 8 & Transforming knowledge & 94 & 78 \\
\hline 9 & Make synthesis & 72 & 78 \\
\hline
\end{tabular}

The average score of HOTS test students in the experimental class is higher than that of the control class, which was 73.68> 70.67. The difference in the average value showed the influence of the group investigation learning model on Students HOTS on the topic of environmental pollution. The group investigation learning model was a cooperative learning model that was deliberately designed to train students to think critically and creatively in solving an environmental problem $[17,18]$. This student activity was included in constructivism, the teacher gives the opportunity to students to find ideas in learning. This is one of the teacher's efforts so that students form their own knowledge [19-22].

For the group investigation learning model students conduct investigations on a topic of environmental pollution in accordance with the plan, followed by analyzing the results by making scientific reports and presented in groups in front of the class. The application of the scientific method continued with class discussions on science subjects that can help direct HOTS [23,24]. The average score based on a HOTS questionnaire in the class with the group investigation method was better than the class using the conventional learning model. This was because with the direct involvement of students in the field, they will be directly involved in the information, and show that students used HOTS [25-28].

The difference in the average HOTS questionnaire score showed the alignment between the test score and the questionnaire score. High test scores have a directly proportional relationship with questionnaire test scores. In the group investigation class, the change/transform indicator has the highest average observation score. This was because students make observations and direct interviews with informants, so that the amount of information obtained causes students to internalize information to be able to solve problems [29-31]. The next step was processing data and presenting information in different forms both in the form of power points and posters. This showed that with the group investigation learning model, students' HOTS can develop compared to conventional learning models. 
For class with conventional learning model methods, the indicator asking questions has the highest score. This was because the use of articles in learning makes students connect the information contained in the article with the previous knowledge and their experience [32-34]. Even though, by using a conventional learning model, the students' HOTS can still develop. This can be seen at the time of discussion that students can answer questions, but those proposed have not focused on solving problems that exist on the topics.

Based on all the HOTS indicators, the indicator recognizes patterns was an indicator that has the largest average difference in the results of observations. This is seen from the difference between the class with the group investigation model and the class using conventional learning models. This was because the student investigation group class can identify any information obtained during the investigation, then students solve the problem by linking every relationship that is in the information, this can increase HOTS [29,35-38].

The score of HOTS ability tests on conventional learning model methods is low compared with the group investigation method, because in conventional classes students do not do learning outside the classroom [39]. This is because learning outside the classroom involves students' ability to observe, investigate problems directly. Learning like this will have an impact on increasing further curiosity to have much information [40-41]. The strength of group investigation emphasizes students to solve problems in groups with colleagues to develop an understanding without fear, because a decision is a group decision [42,43]. The advantages of group investigation methods is to stimulate students to think critically together in their groups, so that they can solve problems [7,44-48].

\section{Conclusions}

Based on the results of the study, it can be concluded that there was an influence of the group investigation learning model on students' HOTS on the topic of environmental pollution. The recommendation of this study was that teachers can apply the group investigation learning model to students. In addition, teachers can also apply other group learning models in order to increase students' HOTS. The use of other learning models based on cooperative learning is also highly recommended so that they can be applied to improve students' HOTS abilities.

\section{Acknowledgements}

The authors would like to thank all the students and teachers who have been participated in this research.

\section{REFERENCES}

[1] Şener, N., Türk, C., \& Taş, E. (2015). Improving Science Attitude and Creative Thinking through Science Education Project: A Design, Implementation and Assessment. Journal of Education and Training Studies, 3(4), 57-67. https://doi.org/10.11114/jets.v3i4.771

[2] Wang, S., \& Wang, H. (2011). Teaching Higher Order Thinking in the Introductory MIS Course: A Model-Directed Approach. Journal of Education for Business, 86(4), 208-213. https://doi.org/10.1080/08832323.2010.505254

[3] Anderson, L. W., Krathwohl, D. R., Airiasian, W., Cruikshank, K. A., Mayer, R. E., \& Pintrich, P. R. (2001). A taxonomy for learning, teaching and assessing: A revision of Bloom's Taxonomy of educational outcomes: Complete edition. New York: Longman.

[4] Teimourtash, M., \& YazdaniMoghaddam, M. (2017). On the Plausibility of Bloom's Higher Order Thinking Strategies on Learner Autonomy: The Paradigm Shift. Asian-Pacific Journal of Second and Foreign Language Education, 2(1), 14. https://doi.org/10.1186/s40862-017-0037-8

[5] Garcia, L. C. (2015). Environmental Science Issues for Higher- Order Thinking Skills (HOTS) Development: A Case Study in the Philippines. In Biology Education and Research in a Changing Planet (pp. 45-54). https://doi.org/10.1007/978-981-287-524-2

[6] Saido, G. M., Siraj, S., Nordin, A. B. Bin, \& Amedy, O. S. A. (2015). Higher Order Thinking Skills Among Secondary School Students in Science Learning. The Malaysian Online Journal of Educational Science, 3(3), 13-20.

[7] Tiruneh, D. T., De Cock, M., Weldeslassie, A. G., Elen, J., \& Janssen, R. (2017). Measuring Critical Thinking in Physics: Development and Validation of a Critical Thinking Test in Electricity and Magnetism. International Journal of Science and Mathematics Education, 15(4), 663-682. https://doi.org/10.1007/s10763-016-9723-0

[8] Tanujaya, B., Mumu, J., \& Margono, G. (2017). The Relationship between Higher Order Thinking Skills and Academic Performance of Student in Mathematics Instruction. International Education Studies, 10(11), 78-85. https://doi.org/10.5539/ies.v10n11p78

[9] Spinola, H. (2016). Environmental literacy in Madeira Island (Portugal): The influence of Demographic Variables. International Electronic Journal of Environmental Education, 6(2), 92-107. https://doi.org/10.18497/iejee-green.52941

[10] Okur-Berbeglu, E. (2015). The Effect of Ecopodagogy-Based Environmental Education on Environmental Attitude of In-service Teachers. International Electronic Journal of Environmental Education, 5(2), 86-110. https://doi.org/10.18497/iejee-green.09988

[11] Jewpanich, C., \& Piriyasurawong, P. (2015). Project-Based Learning Using Discussion and Lesson-Learned Methods via Social Media Model for Enhancing Problem Solving Skills. International Education Studies, 8(6), 24-31. https://doi.org/10.5539/ies.v8n6p24

[12] Seechaliao, T. (2017). Instructional Strategies to Support 
Creativity and Innovation in Education. Journal of Education and Learning, 6(4), 201-208. https://doi.org/10.5539/jel.v6n4p201

[13] DeSchryver, M. (2017). Using the Web as a Higher Order Thinking Partner: Case Study of an Advanced Learner Creatively Synthesizing Knowledge on the Web. Journal of Educational Computing Research (Vol. 55). https://doi.org/10.1177/0735633116667356

[14] Saputri, A. C., Sajidan, S., Rinanto, Y., Afandi, A., \& Prasetyanti, N. M. (2018). Improving Students' Critical Thinking Skills in Cell-Metabolism Learning Using Stimulating Higher Order Thinking Skills Model. International Journal of Instruction, 12(1), 327-342. https://doi.org/10.29333/iji.2019.12122a

[15] Hugerat, M., \& Kortam, N. (2014). Improving higher order thinking skills among freshmen by teaching science through inquiry. Eurasia Journal of Mathematics, Science and Technology Education, 10(5), 447-454. https://doi.org/10.12973/eurasia.2014.1107a

[16] Amstrong, T. (2009). The Whole Brain Solution. Jakarta: Gramedia Widiasarana Indonesia.

[17] Norman, H., Nordin, N., Din, R., \& Ally, M. (2016). Modeling Learner Situation Awareness in Collaborative Mobile Web 2.0 Learning. Malaysian Online Journal of Educational Technology, 4(1), 32-56.

[18] Suryanda, A., Azrai, E. P., \& Wari, N. (2016). Pengaruh Penerapan Model Pembelajaran Group Investigation (GI) Terhadap Kemampuan Berpikir Analisis Siswa Pada Materi Pencemaran Lingkungan. Biosfer: Jurnal Pendidikan Biologi, 9(2), 37-44. https://doi.org/10.21009/biosferjpb.9-2.6

[19] Sigit, D. V., Ernawati, E., \& Qibtiah, M. (2017). Hubungan pengetahuan lingkungan hidup dengan kemampuan pemecahan masalah pencemaran lingkungan pada siswa SMAN 6 Tangerang. Biosfer: Jurnal Pendidikan Biologi, 10(2), 1-6.

[20] Sesen, B. A., \& Tarhan, L. (2010). Promoting active learning in high school chemistry: Learning achievement and attitude. Procedia - Social and Behavioral Sciences, 2(2), 2625-2630. https://doi.org/10.1016/j.sbspro.2010.03.384

[21] Madhuri, G. V, Kantamreddi, V. S. S. N., \& Goteti, L. N. S. P. (2012). European Journal of Engineering Promoting higher order thinking skills using inquiry-based learning. European Journal of Engineering Education, 37:2(March 2013), 37-41

[22] Vidergor, H. E., \& Krupnik-Gottlieb, M. (2015). High order thinking, problem based and project based learning in blended learning environments. In Applied Practice for Educators of Gifted and Able Learners (pp. 217-232). https://doi.org/10.1007/978-94-6300-004-8_11

[23] Kinslow, A. T., Sadler, T. D., \& Nguyen, H. T. (2018). Socio-scientific reasoning and environmental literacy in a field-based ecology class. Environmental Education Research, 4622, 1-23. https://doi.org/10.1080/13504622.2018.1442418

[24] Mercer-Mapstone, L., \& Kuchel, L. (2017). Core Skills for Effective Science Communication: A Teaching Resource for Undergraduate Science Education. International Journal of Science Education, Part B: Communication and Public Engagement, 7(2), 181-201. https://doi.org/10.1080/21548455.2015.1113573

[25] Narayanan, S., \& Adithan, M. (2015). Analysis of Question Papers in Engineering Courses with Respect to HOTS (Higher Order Thinking Skills). American Journal of Engineering Education, 6(1), 1-10.

[26] Mahoney, J. W., \& Harris-Reeves, B. (2019). The effects of collaborative testing on higher order thinking: Do the bright get brighter? Active Learning in Higher Education, 20(1), 25-37. https://doi.org/10.1177/1469787417723243

[27] Husamah, H., Fatmawati, D., \& Setyawan, D. (2018). OIDDE Learning Model: Improving Higher Order Thinking Skills of Biology Teacher Candidates. International Journal of Instruction, 11(2), 249-264.

[28] Yeung, S. yin S. (2015). Conception of teaching higher order thinking: perspectives of Chinese teachers in Hong Kong.

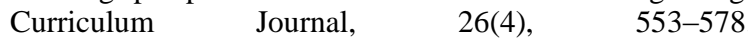
https://doi.org/10.1080/09585176.2015.1053818

[29] Puran, R., Behzadi, M. H., Shahvarani, A., \& Lotfi, F. H. (2017). The Effects of Training and Other Factors on Problem Solving in Students. European Journal of Contemporary Education, 6(3), 448-460. https://doi.org/10.13187/ejced.2017.3.448

[30] Vijayaratnam, P. (2012). Developing Higher Order Thinking Skills and Team Commitment via Group Problem Solving: A Bridge to the Real World. Procedia - Social and Behavioral Sciences, 66, 53-63. https://doi.org/10.1016/j.sbspro.2012.11.247

[31] Kinay, I., \& Bagceci, B. (2016). The Investigation of the Effects of Authentic Assessment Approach on Prospective Teachers' Problem-Solving Skills. International Education Studies, 9(8), 51-59. https://doi.org/10.5539/ies.v9n8p51

[32] Inchamnan, W. (2016). An Analysis of Creative Process Learning in Computer Game Activities Through Player Experiences. IAFOR Journal of Education, 4(2), 119-139

[33] Al-Rahmi, W. M., \& Zeki, A. M. (2017). A model of using social media for collaborative learning to enhance learners' performance on learning. Journal of King Saud University Computer and Information Sciences, 29(4), 526-535. https://doi.org/10.1016/j.jksuci.2016.09.002

[34] Çankaya, I., \& Dag, M. (2017). Comparison of Academic Achievement Levels of Students Beginning the Elementary School at Different Ages. Journal of Education and Practice, 8(3), 140-143.

[35] Tajudin, N. M., \& Chinnappan, M. (2016). The Link between Higher Order Thinking Skills, Representation and Concepts in Enhancing TIMSS Tasks. International Journal of Instruction, 9(2), 199-214. https://doi.org/10.12973/iji.2016.9214a

[36] Musyaddad, A., \& Suyanto, S. (2019). Evoking the four dimensions of student knowledge in ecosystem: effectiveness of real object, web, and blended learning. Biosfer: Jurnal Pendidikan Biologi, 12(2), 194-210.

[37] Golitsyna, I. (2017). Educational Process in Electronic Information-educational Environment. Procedia - Social and Behavioral Sciences, 237, 939-944. 
https://doi.org/10.1016/j.sbspro.2017.02.132

[38] Karpudewan, M., Roth, W. M., \& Abdullah, M. N. S. Bin. (2015). Enhancing Primary School Students' Knowledge about Global Warming and Environmental Attitude Using Climate Change Activities. International Journal of Science Education, 37(1), 31-54. https://doi.org/10.1080/09500693.2014.958600

[39] Ristanto, R. H,. Miarsyah, M., Muharomah, D.R., Astuti, T.A., Aini, S., \& Prihatin., A.I (2019). Light-Board: simple media to learn photosynthesis concepts. International Journal of Advanced Trends in Computer Science and Engineering, 9(1), 299-303. https://doi.org/10.30534/ijatcse/2020/45912020

[40] FitzPatrick, B., \& Schulz, H. (2015). Do Curriculum Outcomes and Assessment Activities in Science Encourage Higher Order Thinking? Canadian Journal of Science, Mathematics and Technology Education, 15(2), 136-154. https://doi.org/10.1080/14926156.2015.1014074

[41] Barak, M., \& Dori, Y. J. (2009). Enhancing higher order thinking skills among inservice science teachers via embedded assessment. Journal of Science Teacher Education, 20(5), 459-474. https://doi.org/10.1007/s10972-009-9141-z

[42] Mutrofin, Degeng, N. S., Ardhana, W., \& Setyosari, P. (2017). The Effect of Instructional Methods (Lecture-Discussion versus Group Discussion) and Teaching Talent on Teacher Trainees Student Learning Outcomes. Journal of Education and Practice, 8(9), 203-209.

[43] Miarsyah, M., Ristanto, R.H., Nurhayati, Mufida, S.N., Suparini, Zharroh, A.E. (2020). Development of adobe flash media integrated into hots on circulation system (af-hots bicycle media). International Journal of Advanced Trends in Computer Science and Engineering, 9(1), 896-903. https://doi.org/10.30534/ijatcse/2020/128912020

[44] Roderer, T., \& Roebers, C. M. (2014). Can you see me thinking (about my answers)? Using eye-tracking to illuminate developmental differences in monitoring and control skills and their relation to performance. Metacognition and Learning, 9(1), 1-23. https://doi.org/10.1007/s11409-013-9109-4

[45] Miller, A. L. (2018). The Role of Creative Coursework in Skill Development for University Seniors. Global Education Review, 5(1), 88-107.

[46] Duran, M., \& Dökme, I. (2016). The effect of the inquiry-based learning approach on student's critical-thinking skills. Eurasia Journal of Mathematics, Science and Technology Education, 12(12), 2887-2908. https://doi.org/10.12973/eurasia.2016.02311a

[47] Heryanti, E., Matondang, M. N., \& Wati, D. A. (2016). Hubungan antara partisipasi siswa dalam kegiatan ekstrakurikuler pramuka dengan sikap kepedulian lingkungan hidup. Biosfer: Jurnal Pendidikan Biologi, 9(2), 54-59.

[48] Azrai, E. P., Ernawati, E., \& Sulistianingrum, G. (2017). Pengaruh gaya belajar david kolb (diverger, assimilator, converger, accommodator) terhadap hasil belajar siswa pada materi pencemaran lingkungan. Biosfer: Jurnal Pendidikan Biologi, 10(1), 9-16. 